Young's inability, within his own theoretical critique, to avoid suppressing the Other and bringing it under the aegis of an intellectually superior Self ironically lends weight to his salient points about the pervasiveness of racism and the capacity of "that ruthless whiteness" (p. 1) to blank out the Other through egotistical historical narrativization and theorization. Still, by demonstrating that shared ethnocentric, Eurocentric, and universalist assumptions infuse the theorizations of radically dissident scholars who have been critically engaged in projects of independence and emancipation in solidarity with peoples outside the West, Young's arguments about the "implacable whiteness" (p. 4) of Hegelian Marxism and the "appropriating narcissism of the West" (p. 49) are persuasive and forceful. It is a challenge to get beyond Young's difficult prose and his dense analysis of complex scholarship, but the rewarding result is a richer appreciation of the political and ethical salience of the poststructuralist project and its fundamental aim to deconstruct "the concept, the authority, and the assumed primacy of, the category of the west” (p. 51).

Ken Montgomery

University of Ottawa

Roderick MacLeod and Mary Anne Poutanen. A Meeting of the People: School Boards and Protestant Communities in Quebec, 1801 - 1998. Montreal and Kingston: McGillQueen's University Press, 2004. Pp.507

It is some years since we have had a study in English of the history of education in Quebec. Thus it is noteworthy to be able to welcome the appearance of such a well-written and thoroughly researched work as A Meeting of the People: School Boards and Protestant Communities in Quebec, 1801 - 1998, by Roderick MacLeod and Mary Anne Poutanen. As the subtitle anticipates, this study deals almost exclusively with the history of Protestant education in Quebec over two centuries. Nonetheless, dealing with a neglected area of Quebec history as it does, it also offers numerous insights as well into rural and small-town Quebec and the ever-changing relations between the anglophone, francophone, and allophone populations of that province. It is an exemplary study of a significant, though minority, community in Quebec as seen through the eyes of one of its main institutions, the elementary and secondary school. As a piece of historical writing, $A$ 
Meeting of the People represents the best of what we might call traditional history: solid, workmanlike research derived from numerous sources with no serious attempt to theorize or perform postmodern pirouettes. The authors simply try to tell the story that most closely approximates the truth as they see it. Thus the reader is free to make his/her own theoretical speculation or inter-provincial comparisons.

And there are many comparisons to be made, especially with Ontario educational history. As Protestant education in Quebec evolved over the years it shifted from representing schooling for a religious minority to become an inclusive, mainly English-language institution that increasingly resembled public schooling across North America. For example, the authors show how in the nineteenth century the Protestant school system represented community-activated as opposed to state or church-activated schooling. Herein they follow the Lawr-Gidney-Millar thesis for Upper Canada/Canada West common schooling as opposed to the social control thesis of KatzPrentice-Houston. Similarly, their approach offers a broad commentary over two centuries on rural education, allowing them to cite in their footnotes comparable works on, for example, British Columbia rural education.

The analysis in this book is a telling antidote to the influential perspective of Louis-Philippe Audet, the dean of Quebec educational historians. In much the same way as Charles Phillips and F. Henry Johnson did for the educational history of English Canada before 1970, Audet held sway in Quebec historiography. With these historians state initiatives were uppermost; things didn't get done without great men like Egerton Ryerson and Jean-Baptiste Meilleur in charge. Consequently, parents, teachers, and school board trustees tended to be viewed in a negative light as ignorant, uncaring, disruptive, or even corrupt. A Meeting of the People serves as a corrective to this perspective while carefully distinguishing the divergent traditions of Protestants and Catholics in Quebec.

This book's canvas is extremely broad. It ranges in time from the Royal Institution for the Advancement of Learning in 1801 to the dissolution of confessional school boards in 1998, and in space from the School Board of Greater Montreal to the rural communities of the Eastern Townships and the Gaspésie. Each chapter is introduced with a small representative (to the topic) local story that serves effectively to catch the reader's interest. Then the authors launch into a detailed, well-documented analysis of the topic or time period. One of the authors' main objectives is to establish that Protestant schools and school boards were particularly crucial for the survival of the Protestant communities in Quebec. This fact is underlined by their contention that many Protestant communities had schools before they had churches. The reverse was, of course, true of the Catholic communities because of the predominance of the church in schooling. 
Thus the book considers "the school board as both a window on to communities and a vehicle through which communities expressed their educational needs" (p. 8).

The story of Protestants in Quebec is also the story of anglophones, including Jews, who were considered Protestant for school purposes, as well as Greeks, Italians, and other immigrants who wished to have their children educated in English. But curiously the Protestant community in this case includes a small number of francophones and excludes a large number of English-speaking Catholics. In nineteenth-century Quebec, as elsewhere in Canada, religion was more important than the language of instruction in public education. Accordingly, in Upper Canada/Canada West schools used various languages for instruction: English, French, German, Algonquian. It was the question of religion in the schools that raised hackles, as evidenced in the bitter separate school controversy between Catholics and Protestants and even Bishop Strachan's contention that there should be Anglican separate schools. This situation contrasts with the abolition of confessional school boards in Quebec, a campaign that commenced in the 1970s and culminated with the abolition of confessional boards in 1998.

In the opening chapters the authors establish well the origins of Protestant schooling in Quebec from the days of the Royal Institution up to Confederation. During this period the strictly denominational features of this system became more and more non-denominational Protestant and thus came to resemble those of Ontario and other parts of North America - what Ryerson referred to as common schools and what eventually became known as "public" schools. However, in Catholic eyes the common school ideal became suspect because its non-denominationalism became identified with assimilation and liberalism, the basis of these reforms. Thanks to the efforts of A.T. Galt, suitable provisions were made in the B.N.A. Act for Quebec's dual confessional system. The entire pre-Confederation era is aptly handled although one might have expected a more extensive discussion of the impact on education of Lord Durham's Report and also mention of the unique experiment of monitorial schools in Montreal, thanks to the work of Joseph Lancaster (1829-33). Bruce Curtis' recent "Lancaster in Montreal," published in this journal (Spring 2005) after the appearance of this book, provides all the necessary details.

After Confederation, first in the city of Montreal and then elsewhere, high schools began to pop up, with students divided into "classical" and "commercial" streams, as they were in Ontario after 1871 in the collegiate institute and vocational school. But high school attendance was severely restricted in numbers. School attendance (not made compulsory until 1943) depended on whether or not the child was needed at home to perform household chores or to fill in if there was sickness. By the age of twelve, paid labour outside the home 
proved attractive for the sake of the family economy until well after 1920. The cycle of industrial labour thus paralleled that of agricultural labour as children approached their teen years. It wasn't until the last half of the last century that the majority of young people were expected to complete secondary school. In fact it was only in 1964 that attendance at high school was made compulsory in Quebec, much later than anywhere else in Canada.

Chapter V, on rural schooling, demonstrates how one-room schoolhouses remained a key feature of Protestant education in Quebec until the 1940s. As elsewhere, many rural school boards resisted the determined march towards consolidation. Significantly, the authors give more credit to parents for concern about their children's education than school inspectors (and most historians) usually do. They conclude by stating: "Children from large rural families probably found the experience of attending a one-room school not all that different from their lives at home and certainly more comforting than having to be bused to a consolidated school far away" (p. 138). To improve the quality of rural teaching and to attempt to stem teacher transience, Macdonald College was opened in Ste. Anne de Bellevue in 1907. This proved a boon to the preparation of rural teachers. (Incidentally, the McGill Normal School, which was primarily for urban teachers, was opened in 1845.) Women's Institutes and the Home and School movement also played a role in improving rural school conditions.

In a chapter entitled "Honorary Protestants" the authors recount the interesting story of Jewish education in the public schools of Quebec. Jews were regarded "for educational purposes" as Protestants and their taxes were directed towards Protestant boards. Jews preferred sending their children to Protestant schools over the Catholic ones because English was the language of instruction and they were sometimes not welcomed in the Catholic schools. As Mordecai Richler and others have pointed out, anti-Semitism was rife in Quebec, especially in the 1930s.

During the twentieth century the similarities between Quebec's Protestant system and the public schools of English Canada increased. This was so with respect to curriculum, pedagogy, and other aspects of educational reform, including rural school consolidation and the spread of secondary schooling. Some examples included instilling patriotic values (love of Britain, Empire Day, and Anglo-Saxon values); cadet corps; organized sports programs and participation in athletic events as "a way of letting young people blow off steam" (p. 239). Out-ofschool organizations lobbied school boards to promote their respective interests: temperance education ("temperance and science") by the Women's Christian Temperance Union, British Imperialism by the I.O.D.E., rural and agricultural education by the Women's Institute, and so forth. Public health measures, including vaccination, mental hygiene through guidance and counselling, and eventually sex 
education in the 1960s-'70s all had their proponents. Public schooling became much more than the 3Rs. In the 1930s progressive education with its emphasis on integrated learning and individual pupil initiative became a watchword in Quebec Protestant schools no less than elsewhere in English Canada.

In the post-World War II era the struggle to reduce rural-urban disparity led to increased busing and school consolidation. By the 1960s the Protestant population in rural Quebec was thinning out and many small boards were abolished in 1972 by provincial legislation. Following the recommendations of the Parent Report in 1963 the decision was made to establish fifty-five regional school boards, nine of them Protestant. Large regional high schools with "modern" facilities followed apace. Features such as gyms, chemistry labs, libraries, sometimes a swimming pool, sewing rooms, and music rooms became evident in Protestant high schools, but were not generally associated with Catholic schools, a fact duly noted by the Parent Commission. Such large high schools became "as selfcontained as shopping malls" (p. 310), but on the downside ruptured the connection between school and community, providing further challenges to the rural Protestant population.

Post-World War II immigration from European countries, such as Italy and Greece, added considerably to the non-Protestant/nonCatholic majority of children to be found in many Protestant schools, especially in the Montreal region. Table 13 (p. 359) shows the majority of students in Protestant schools in 1991 were non-Protestant and Catholic. Thus the prewar complexion of these schools was dramatically changed. By the late 1960s the Protestant system was functioning in two languages. By the 1980s the Parti Québecois government supported linguistic schools over confessional ones. With Bill 180 passed in 1998 the PQ finally fulfilled the Parent Commission's recommendation from three decades before to abolish confessional school boards, a measure that required a constitutional amendment granted by the Parliament of Canada in 1997. Two years later the Proulx Report recommended no specific religious instruction in the schools of Quebec, a likely signpost to the future principally affecting the former Catholic schools. The authors end gloomily by concluding "the legacy of Protestant education has been largely forgotten and its possible benefits to modern Quebec society overlooked" (p. 403).

In a long manuscript that is remarkably error-free, three minor errors bear noting: the author of one of the best studies of the guerre des éteignoirs is "Wendie," not "Wendy," Nelson and her M.A. thesis was done under the supervision of Jack Little at Simon Fraser University, not the University of Ottawa. Also, the caption for Map 1 should presumably read "1000" instead of "100" kilometers.

This book is an important contribution to the field of Quebec and Canadian educational history. Although the readership is likely to be 
quite limited because of its specialized nature, the authors deserve high praise for the thoroughness and care with which they have carried out their project.

J. Donald Wilson

University of British Columbia

\section{Andrée Dufour et Micheline Dumont. Brève histoire des institutrices au Québec de la Nouvelle-France à nos jours. Montréal, Boréal, 2004, 220 pages.}

Les auteures, Andrée Dufour et Micheline Dumont, présentent ici une petite monographie sur les institutrices québécoises depuis la colonie française jusqu'à nos jours. Elles s'appuient sur leurs travaux antérieurs en histoire de l'éducation, nombreux et faisant autorité, pour se livrer à un exercice de synthèse.

Ces travailleuses, dans les sociétés d’Ancien Régime, se voyaient confier un mandat de christianisation de la jeune génération. En fait, hommes et femmes désireux de se livrer à cette occupation devaient en avoir la permission des autorités religieuses et se soumettre aux directives de celles-ci. En Nouvelle-France, au $17^{\mathrm{e}}$ siècle, deux ordres féminins s'illustrèrent surtout : les Ursulines et les Sœurs de la Congrégation de Notre-Dame. Au $19^{\mathrm{e}}$ et au $20^{\mathrm{e}}$ siècle, de nouvelles congrégations très souvent créées en terre canadienne vinrent compléter cet effectif.

Le passage au $19^{\mathrm{e}}$ siècle amena son lot de nouvelles exigences éducatives, liées au développement du capitalisme marchand et à la mise en place des institutions parlementaires. La formation du croyant se compléta, en quelque sorte, de celle de l'acteur économique et de l'électeur. Cela correspondit à l'arrivée, importante, de femmes laïques dans ce domaine. La mise en place d'un réseau scolaire permanent, dans la seconde moitié de ce siècle, où l'autorité centrale et des commissions scolaires devaient partager les responsabilités, conforta la place des institutrices en généralisant l'accès à l'école : le souci d'économie, la reconnaissance d'une affinité «naturelle » des femmes pour ce genre de travail et, bien sûr, la volonté de celles-ci d'agir dans ce secteur favorisèrent leur présence.

$\mathrm{Au} 20^{\mathrm{e}}$ siècle, au gré d'attentes plus grandes quant aux apprentissages nécessaires pour entrer dans la vie, dans un contexte de spécialisation accrue de l'ensemble de la main-d'œuvre, non seulement les personnes désireuses de devenir institutrices devaient-elles se soumettre à une préparation plus longue, mais obéir dans leur tâche 